\title{
Lymphocyte tubular structures in rheumatoid arthritis
}

\author{
ANTOINE DRYLL, PAULE CAZALIS, AND ANTOINE RYCKEWAERT \\ From the Laboratoire de Microscopie Electronique, Clinique Rhumatologique, Hôpital Lariboisière, Paris, \\ France
}

SUMMARY Two types of lymphocyte tubular structures were studied by electron microscopy in $80 \stackrel{\circ}{\circ}$ patients with classic or definite rheumatoid arthritis (RA). Fifteen patients with unequivocal systemic lupus erythematosus (SLE) and 10 healthy persons were studied as controls. Lymphocyte tubulo-. reticular structures were found in 13 of the 80 patients with RA and in 10 of the 15 patients with SLE. No tubuloreticular structures were found in any of the healthy subjects. In the RA patients $N$ antinuclear antibodies, LE cell phenomenon, and chlorambucil treatment were associated signifi-음 cantly with these inclusions but disease activity was not related to their presence. In cases in whichtubuloreticular structures were present the number of cells containing inclusions was on average $\mathbb{D}$ much lower in patients with RA than in those with SLE. Lymphocyte tubular parallel arrays were $\frac{\mathbb{D}}{\mathbb{D}}$ found in all the patients with RA and SLE and in all the healthy persons. In all three groups the $\frac{\bar{T}}{0}$ average number of cells containing parallel tubular arrays was similar.

Since tubuloreticular structures (TRS) in the renal endothelium in systemic lupus erythematosus (SLE) were first described (Gyökey et al., 1969) there have been many reports of their presence in the cytoplasm of human lymphocytes. TRS have been found in the vascular endothelium and lymphocytes in various diseases of apparently independent pathogenesis (Schaff et al., 1973; Landolt et al., 1976) and there has been no convincing explanation for their presence. They have often been found in SLE (Györkey et al., 1972; Bariéty et al., 1973; Grimley et al., 1973) and TRS in lymphocytes seem to be related to disease activity (Klippel et al., 1974). However, they have been reported in only a few cases of rheumatoid arthritis (RA) (Györkey et al., 1972; Bariéty et al., 1973).

Another type of lymphocyte tubular inclusion are parallel tubular arrays (PTA). These have been found in lymphocytes of healthy persons (Huhn, 1968; Bariéty et al., 1971; Brunning and Parkin, 1975), but they are more common in various diseases (Brunning and Parkin 1975; Belcher et al., 1975), particularly connective tissue diseases (Hovig et al., 1968; Bariéty et al., 1971).

Our aim was to ascertain the incidence of these TRS and PTA lymphocyte inclusions in RA and to

Received for publication 31 January 1977 discover whether they were related to dise 0 . activity.

\section{Patients and methods}

Eighty patients with classical or definite RA accord- $\frac{Q}{-}$ ing to the American Rheumatism Association (ARA) criteria (Ropes et al., 1958) were included in a prospective study. Of these 80 patients 14 had antinuclear antibodies (ANA) and a negative LE cell $\stackrel{-}{-}$ test, two had ANA and a positive LE cell test, and two had a positive LE cell test and no ANA. Noneother of the ARA preliminary criteria for SLE 3 . (Cohen et al., 1971) were found. Thirteen patients were being treated with chlorambucil at the time of $₹$ the blood sampling. We examined as controls 150 patients who had unequivocal SLE according to the ARA preliminary criteria and 10 healthy persons.

Disease activity in RA was assessed on the following indices: erythrocyte sedimentation rate (ESR), ㄱ approximate rheumatoid factor concentration in F IIN latex and Rose-Waaler reactions, and the need for N prednisone treatment.

ULTRASTRUCTURAL STUDY

Buffy coat samples were prepared from $30 \mathrm{ml}$ of heparinised blood after sedimentation for $60^{\circ}$ minutes at $37^{\circ} \mathrm{C}$. The supernatant was centrifuged at $\bar{O}$ $400 \mathrm{~g}$ in Wintrobe tubes for 20 minutes. The pellet $\mathbb{\nabla}$ 
was fixed in a $2.5 \%$ glutaraldehyde solution in phosphate buffer for two hours then postfixed in a $2 \%$ osmium tetroxide solution in phosphate buffer for one hour. After dehydration with graded alcohols the fragments were embedded in Spurr's resin, cut with a Reichert OmU2 ultramicrotome, and stained with uranyl acetate and lead citrate. Ultrathin sections were examined on a Philips EM 300 electron microscope.

We examined 800 lymphocytes and related mononuclear cells from each patient. To avoid recounting serial sections through the same cell we examined eight blocks in each case and counted a mean of 100 mononuclear cells per block obtained by examination of a minimum of four grids.

\section{Results}

\section{LYMPHOCYTE TUBULORETICULAR}

\section{STRUCTURES}

Out of the 80 patients with RA 13 had TRS in their lymphocytes. The incidence of lymphocyte TRS in relation to the presence of ANA, LE cell phenomenon, and to chlorambucil treatment is shown in the Table. TRS were found in 10 of the 15 patients with SLE. No TRS were found in any of the 10 healthy controls.

Table Incidence of lymphocyte TRS in patients with $R A$

\begin{tabular}{|c|c|c|}
\hline \multirow[t]{2}{*}{ Case } & \multicolumn{2}{|c|}{ Lymphocyte TRS } \\
\hline & Present & Absent \\
\hline $\begin{array}{l}\text { RA with ANA and/or LE cell phenomenon } \\
\text { RA treated with chlorambucil } \\
\text { RA without ANA, LE cell phenomenon or } \\
\text { chlorambucil treatment }\end{array}$ & $\begin{array}{l}9 * \\
5 *(2) \dagger \\
1\end{array}$ & $\begin{array}{l}9 \\
8(1) \dagger \\
51\end{array}$ \\
\hline
\end{tabular}

${ }^{*} \mathrm{P}<0.001$ (corrected $x^{2}$ test of Yates) compared with cases of RA without ANA, LE cell phenomenon, or chlorambucil treatment. $\dagger$ Number of patients with ANA or LE cell phenomenon.

The ultrastructural pattern of the lymphocyte TRS was similar to that previously described. Inclusions (Fig. 1) were located in the endoplasmic reticulum or membranous compartments apparently connected with this reticulum. They had a net-like, reticular arrangement.The diameter of constituent tubules was $20 \mathrm{~nm}$ to $30 \mathrm{~nm}$. The mean incidence of inclusions was much lower in RA (one positive cell for about 150 mononuclear cells) than in SLE (one positive cell for about 50 mononuclear cells).

Disease activity was compared in TRS-positive and TRS-negative patients with RA. No difference in ESR, rheumatoid factor concentration, or need for prednisone treatment was found.
LYMPHOCYTE PARALLEL TUBULAR ARRAYS PTA were found in mononuclear cells in all the patients with RA and in all the SLE and healthy controls. In all the ultrastructural pattern of PTA was similar to that previously described. These inclusions (Fig. 2) consist of parallel arrays of tubular structures in wall-to-wall contact with each other. Arrays of tubules often appeared to be orientated at $90^{\circ}$ to adjoining arrays within the same inclusion. The diameter of the constituent tubules was $15 \mathrm{~nm}$ to $30 \mathrm{~nm}$. The inclusions, though usually bounded by membrane, sometimes had no limiting membrane. They were usually near to mitochondria, some of which had a degenerative pattern, or near the Golgi apparatus (Fig. 3).

The number of PTA per mononuclear cell varied considerably from cell to cell. Rarely single, they were most often grouped in fair numbers. The number of PTA-positive cells differed considerably from subject to subject, varying from 1 to $8 \%$ of the mononuclear cells. However, the average number was similar in cases of RA, SLE, and in healthy controls.

\section{Discussion}

\section{LYMPHOCYTE TUBULORETICULAR}

STRUCTURES

The significance of these structures remains obscure. Their resemblance to nucleocapsids of paramyxovirus was pointed out when they were first described (Györkey et al., 1969), but further studies have refuted this analogy (Helder et al., 1975). The biological nature of TRS has not been resolved. They may consist principally of phospholipids and acidic glycoproteins (Schaff et al., 1973). The presence of nucleic acids has been suggested (Helder et al., 1975; Landolt et al., 1976). They are most often found in patients with SLE, almost always in renal biopsies (Györkey et al., 1972; Bariéty et al., 1973) and commonly in lymphocytes (Bariéty et al., 1971; Györkey et al., 1972; Grimley et al., 1973). The presence of TRS in the mononuclear cells of 10 of our 15 patients with SLE is in accordance with previous reports.

TRS seem to be uncommon in rheumatoid arthritis. Györkey et al. (1972) failed to find them in renal biopsies and Bariéty et al. (1973) found them in only two out of six patients with RA. They were present in synovial membrane in four patients with RA (Györkey et al., 1972) but they were not found in another study of 24 patients with RA (Dryll et al., 1977). Nor were they found in lymphocytes by Bariéty et al. (1971) or by Grimley et al. (1973). Györkey et al. (1972) have reported one case of RA with lymphocyte TRS.

That we found lymphocyte TRS in 13 of our 80 


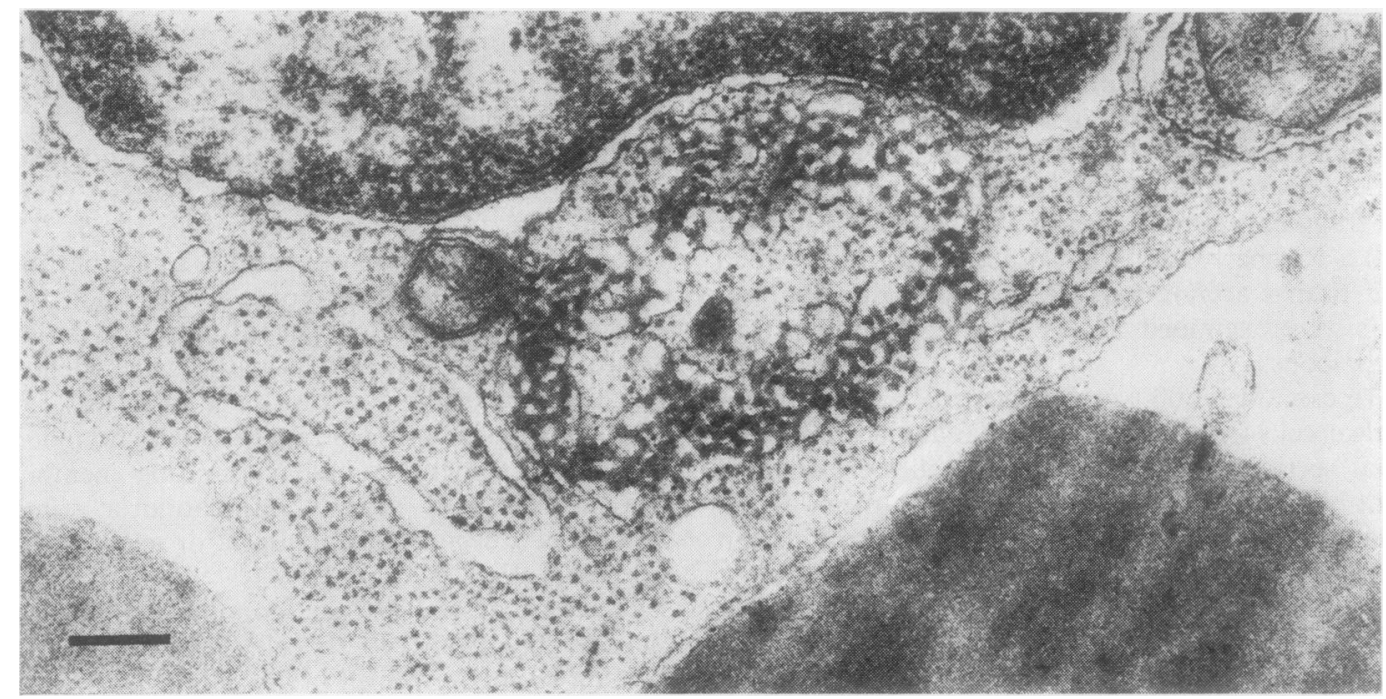

Fig. 1 TRS in mononuclear cell of patient with RA and ANA and LE cell phenomenon. (Original magnification $\times 20000$. Bar $=0.25 \mu \mathrm{m})$

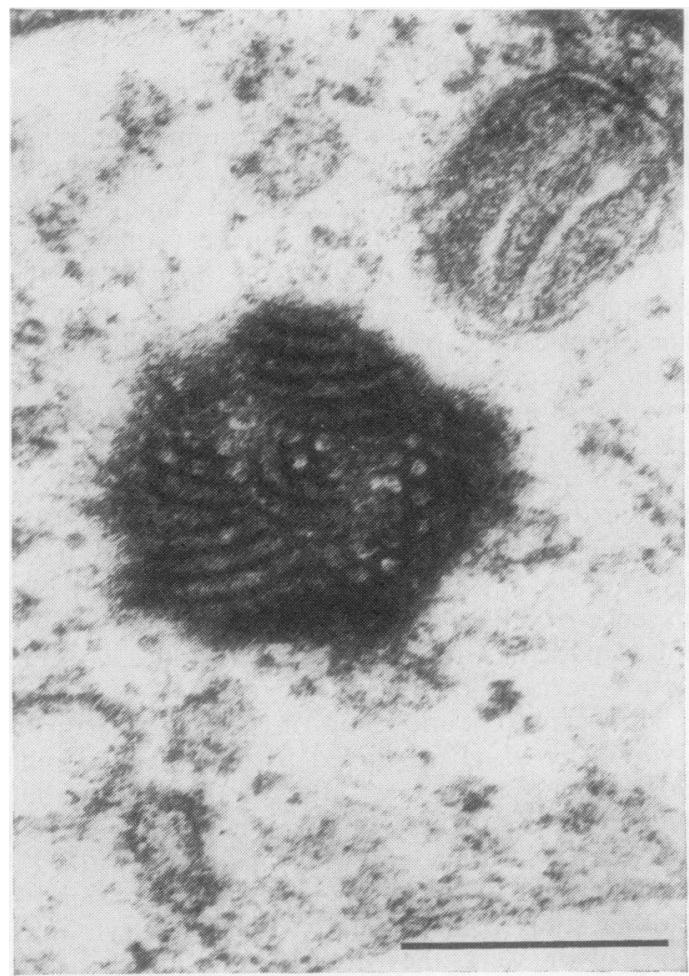

FIG. 2

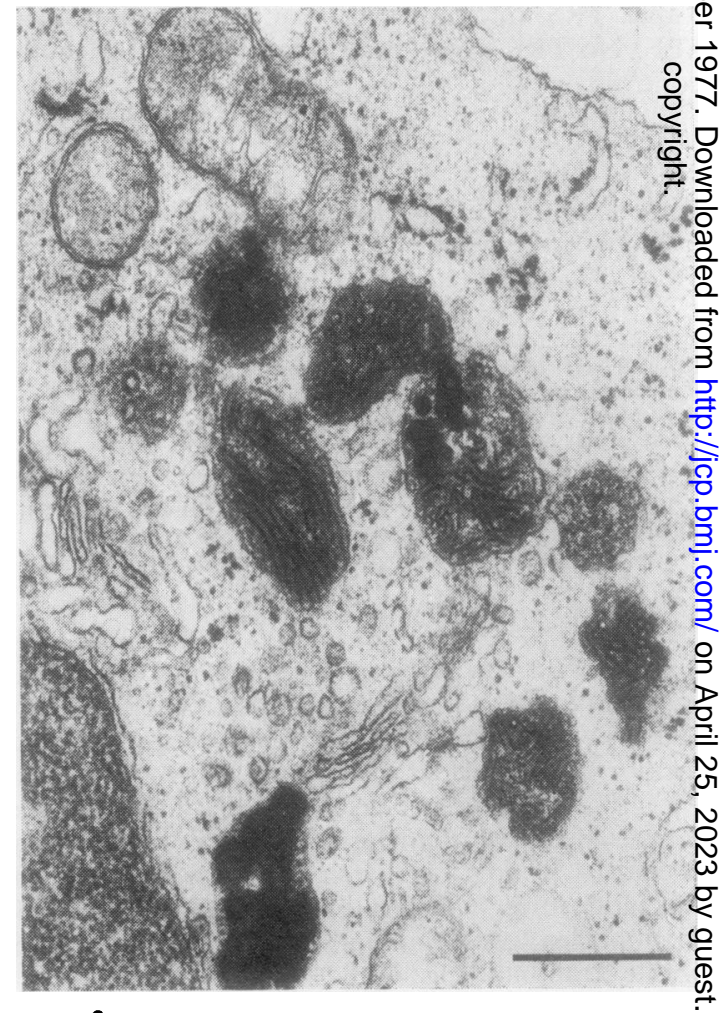

FIG. 3

Fig. 2 PTA without membrane in lymphocyte of healthy control. (Original magnification $\times 55000 . B a r=0 \cdot 25 \mu m$ ) Fig. 3 Group of membrane-bounded PTA in mononuclear cell of healthy control. Note vicinity of PTA with degenerated mitochondria and Golgi apparatus. (Original magnification $\times 33000$. Bar $=0 \cdot 25 \mu \mathrm{m}$ ) 
patients with RA may be because we examined more patients and more mononuclear cells than previous investigators. Lymphocyte TRS are rare in RA. Only one among the 52 cases of RA without ANA or LE cell phenomenon and not on chlorambucil treatment was TRS positive.

The association of lymphocyte TRS, ANA, and LE cell phenomenon is often found in SLE. In our RA patients, ANA or LE cell phenomenon, or both, were significantly associated with lymphocyte TRS. Nine of the 13 TRS-positive RA patients had ANA and/or LE cell phenomenon and 9 of the 18 patients with ANA and/or LE cell phenomenon were TRS positive. The meaning of these associations in RA remain unclear. In spite of the absence of other criteria for SLE in all our patients the presence of lymphocyte TRS may provide further evidence for the existence of transitional forms between RA and SLE.

Disease activity has been found to be greater in patients with SLE when lymphocyte TRS were present than when they were not (Klippel et al., 1974). In our patients with RA disease activity was the same in both TRS-positive and TRS-negative patients.

Immunosuppressive treatment possibly favours the appearance of TRS in renal biopsies (Bariéty et al., 1974). In our study chlorambucil treatment was significantly associated with lymphocyte TRS. Out of 13 RA patients treated with chlorambucil five were TRS positive. Two of the five had been TRS-negative before treatment. In two of the five ANA or LE phenomena were present. However, even when ANA or LE cell phenomena were absent the association between chlorambucil treatment and lymphocyte TRS remained significant.

\section{LYMPHOCYTE PARALLEL TUBULAR}

ARR A Y S

The significance of lymphocyte PTA is controversial. Huhn (1968) thought PTA were a new cytoplasmic organelle in normal lymphocytes. Hovig et al. (1968) thought they could be related to the RA or to the treatment, or both. White (1972), Belcher et al. (1975), and Brunning and Parkin (1975) suggested that, though present in normal lymphocytes, they might be more common in various diseases. Bariéty et al. (1971) found PTA increased in SLE but they did not find them in RA. We found PTA in all patients with RA and SLE and in all healthy controls and the average number of PTA-bearing cells was similar.

The nature and the origin of these structures remain uncertain. The cytochemical study by Hovig et al. (1968) suggested that they might be phospholipidic in nature, Hovig et al. (1968) and Bariéty et al. (1971) thought that they might originate from the mitochondria. White (1972) suggested they might be related to endoplasmic reticulum, and Brunning and Parkin (1975) that they might arise from the centriole. We have noticed only that these structures are often near mitochondria some of which have a degenerative pattern and the Golgi apparatus.

In conclusion, lymphocyte TRS are uncommon in RA. Their presence is significantly associated with ANA, LE cell phenomenon, and chlorambucil treatment. In TRS-positive cases the average number of cells with TRS was much lower in cases of RA than in those of SLE. On the other hand, PTA were present in all patients with RA and SLE and in all healthy controls, and the average number of PTA-bearing cells was the same in the three groups.

We thank Professor M. F. Khan, who referred some of the patients included in this study; Professor $\mathbf{J}$. Bariéty and Dr J. F. Girard for their critical review of the manuscript and Miss M. F. Corruble for her technical assistance. The work was supported by a grant from INSERM Paris, C.R.L. No. 74. 2.102.4.

\section{References}

Bariéty, J., Amor, B., Kahan, A., Balafrej, J. L., and Delabarre, F. (1971). Ultrastructural anomalies in mononuclear cells of peripheral blood in S.L.E: presence of virus-like inclusions. Revue Européene d'Etudes Cliniques et Biologiques, 16, 715-720.

Bariéty, J., Idatte, J. M., Bedrossian, J., Callard, P., and Appay, M. D. (1974). Frequency of renal intraendothelial microtubular inclusions in kidney transplants: an electron microscopy study. Transplantation, 17, 140142.

Bariéty, J., Richer, D., Appay, M. D., Grossetete, J., and Callard, P. (1973). Frequency of intra endothelial 'virus-like' particles: an electron microscopy study of 376 human renal biopsies. Journal of Clinical Pathology, 26, 21-24.

Belcher, R. W., Czarnetzki, B. M., and Campbell, P. B. (1975). Ultrastructure of inclusions in peripheral blood mononuclear cells in sarcoidosis. American Journal of Pathology, 78, 461-468.

Brunning, R. D. and Parkin, J. (1975). Ultrastructural studies of parallel tubular arrays in human lymphocytes. American Journal of Pathology, 78, 59-70.

Cohen, A. S., Reynolds, W. E., Franklin, E. C., Kulka, J. P., Ropes, M. W., Shulman, L. E., and Wallace, S. L. (1971). Preliminary criteria for the classification of systemic lupus erythematosus. Bulletin on the Rheumatic Diseases, 21, 643-648.

Dryll, A., Lansaman, J., Cazalis, P., Peltier, A. P., and Seze, S. de (1977). Light and electron microscopy study of capillaries in normal and inflammatory human synovial membrane. Journal of Clinical Pathology, 30, 556-562.

Grimley, P. M., Decker, J. L., Michelitch, H. J., and Frantz, M. M. (1973). Abnormal structures in circulat- 
ing lymphocytes from patients with systemic lupus erythematosus and related diseases. Arthritis and Rheumatism, 16, 313-323.

Györkey, F., Min, K. W., Sinkovics, J. G., and Györkey, P. (1969). Systemic lupus erythematosus and myxovirus (Letter). New England Journal of Medicine, 280, 333.

Györkey, F., Sinkovics, J. G., Min, K. W., and Györkey, P. (1972). A morphologic study on the occurrence and distribution of structures resembling viral nucleocapsids in collagen diseases. American Journal of Medicine, 53, 148-158.

Helder, A. W., Feltkamp-Vroom, T. M., and Van Loghem, J. J. (1975). A comparative morphological study of tubular structures in human tissues and nucleocapsids of measles virus. Journal de Microscopie, 23, 1-16.

Hovig, T., Jeremic, M., and Stavem, P. (1968). A new type of inclusion bodies in lymphocytes. Scandinavian Journal of Haematology, 5, 81-96.

Huhn, D. (1968). Neue Organelle im peripheren Lymphozyten? Deutsche medizinische Wochenschrift, 93, 2099-2100.
Klippel, J. H., Grimley, P. M., Decker, J. L., anơ Michelitch, H. J. (1974). Lymphocyte tubuloreticulae structures in lupus erythematosus: correlation with disease activity. Annals of Internal Medicine, 81, 355 357.

Landolt, A. M., Ryffel, U., Hosbach, H. U., and ,Wyler등 R. (1976). Ultrastructure of tubular inclusions in endothelial cells of pituitary tumours associated with acromegaly. Virchows Archiv A, Pathological Anatomy and Histology, 370, 129-140.

Ropes, M. W., Bennett, G. A., Cobb, S., Jacox, R., and Jessar, R. A. (1958). 1958 revision of diagnostic_ criteria for rheumatoid arthritis. Bulletin on the Rheumatic Diseases, 9, 175-176.

Schaff, Z., Barry, D. W., and Grimley, P. M. (1973) Cytochemistry of tubuloreticular structures in lympho- $-\dot{\omega}$ cytes from patients with systemic lupus erythematost 50 and in cultured human lymphoid cells: comparison to $a^{6}$ paramyxovirus. Laboratory Investigation, 29, 577-586.

White, J. G. (1972). Giant organelles containing tubules in Chediak-Higashi lymphocytes. American Journal of Pathology, 69, 225-238. 